\title{
Postoperative structural complications after microscopic transsphenoidal surgery of GH secreting pituitary adenomas
}

\author{
Marcelo Lemos Vieira da Cunha1, Ana Luiza Brunelli Pletz², Luis \\ Alencar Biurrum Borba ${ }^{3}$, Cesar Luiz Boguszewski ${ }^{4}$ \\ Departamento de Neurocirurgia do Hospital Universitário Evangélico de Curitiba, Curitiba, PR, Brazil.
}

\begin{abstract}
Objective: Analyzing the rate of structural complications after transsphenoidal surgery for removal of growth hormone (GH) secreting pituitary adenomas. Methods: Retrospective study of 58 patients who underwent microscopic transsphenoidal neurosurgery for $\mathrm{GH}$ secreting pituitary adenomas exeresis in Curitiba, Parana state, Brazil, between 1998 and 2011 by the same neurosurgeon. The Criteria for diagnosis of complications were clinical. Results: Five $(8,6 \%)$ of the 58 patients who underwent transsphenoidal surgery developed postoperative anatomical complications, which was due to sixth cranial nerve palsy $(3,4 \%)$, surgical wound infection $(1,7 \%)$ and CSF fistula $(3,4 \%)$. Conclusion: The rate of postoperative complications observed in the present study is likely the literature review. There is a drop in the rate of complications with increasing experience of the neurosurgeon.
\end{abstract}

\section{KEYWORDS}

Acromegaly, growth hormone, growth hormone-secreting pituitary adenoma, postoperative complications, microsurgery.

\section{RESUMO}

Complicações estruturais pós-operatórias após microcirurgia transesfenoidal de adenomas pituitários produtores de GH

Objetivo: Analisar a taxa de complicações anatômicas após cirurgia transesfenoidal para remoção de adenoma hipofisário produtor de hormônio do crescimento (GH). Métodos: Estudo retrospectivo de 58 pacientes operados por microcirurgia transesfenoidal para exérese de adenomas pituitários produtores de GH em Curitiba, Paraná, Brasil, entre 1998 e 2011, realizados pelo mesmo neurocirurgião. Diagnóstico das complicações foi clínico. Resultados: Dos 58 pacientes submetidos à cirurgia transesfenoidal, 5 $(8,6 \%)$ desenvolveram complicações anatômicas, 3,4\% foram em decorrência de paresia temporária do sexto nervo craniano, $1,7 \%$, de infecção da ferida operatória, e 3,4\%, de fístula liquórica. Conclusão: A taxa de complicações pós-operatórias observada no presente estudo está semelhante à da revisão literária. Há uma queda no índice de complicações conforme aumenta a experiência do neurocirurgião.

\section{PALAVRAS-CHAVE}

Acromegalia, hormônio do crescimento, adenoma hipofisário secretor de hormônio do crescimento, complicações pós-operatórias, microcirurgia.

1 Neurosurgeon of Hospital Regional do Oeste, member of the Brazilian Society of Neurosurgery Chapecó, SC, Brazil.

2 Medical student of Federal University of Paraná (UFPR), Curitiba, PR, Brazil.

3 Surgery PhD, Head of Neurosurgery Departament of Evangelic University Hospital from Curitiba, PR, Brazil.

4 Endocrinology PhD and Head of Endocrinology and Metabolism, Hospital de Clínicas, UFPR, Curitiba, PR, Brazil. 


\section{Introduction}

Acromegaly is a rare disorder caused by overproduction of growth hormone, most commonly due to pituitary adenomas, with an estimated prevalence of 40 to 125 per million, and incidence of 3 to 4 new cases per million. ${ }^{1}$ Clinical manifestations include somatic enlargement, jaw overgrowth, sleep apnea syndrome, cardiomyopathy, visual field loss, osteoarthropathy, diabetes mellitus, menstrual irregularities and sexual dysfunction. The insidious onset of acromegaly frequently leads to a delay in diagnosis, and patients with this disorder have an increased mortality risk.

Therapy goals are: to control biochemical indices of disease and tumor size; to prevent local mass effects; to reduce signs and symptoms; and to prevent medical comorbidities and early mortality. Neurosurgery is considered the first-line option for treatment of acromegaly. It is recommended as primary therapy for all patients with microadenomas, and for patients with macroadenomas and mass effects, or with a high predicted chance for cure. ${ }^{1}$ Approximately $40-60 \%$ of macroadenomas are unlikely to be controlled with surgery alone. ${ }^{2}$ Medical therapy and radiotherapy also have a role, usually as adjuvant treatment. Contraindications to surgery include general debility, advanced age, patient refusal, and severe cardiomyopathy or respiratory disease., ${ }^{2,3}$

Transsphenoidal neurosurgery remains the primary therapy for most patients. It is a safe and effective procedure. The rate of postoperative complications is low and inversely proportional to the surgeon's experience. ${ }^{1-5}$ Complications include pituitary dysfunction, meningitis, cerebrospinal fluid fistulas, carotid artery injury, neurological and nasal complications.
The aim of this article is to analyze the incidence of postoperative structural complications after microscopic transsphenoidal neurosurgery and to compare the rates observed in our series with those recently reported in the literature.

\section{Methods}

The present study concerned patients with $\mathrm{GH}$ secreting pituitary adenomas. All patients underwent microscopic transsphenoidal neurosurgery between July 1998 and June 2011, by the senior neurosurgeon Luis Alencar Biurrum Borba. The series consisted of 58 patients (23 female and 35 male), whose age ranged from 10 to 70 years, with a mean age of $42,5 \pm 12,4$ years (Figure $1)$. Four patients $(6,9 \%)$ were diagnosed with pituitary microadenoma, while $54(93,1 \%)$, with macroadenoma.

The criteria for diagnosing acromegaly were: elevated serum concentration of insulin-like growth factor- 1 (IGF-1) according to age and sex, basal serum growth hormone $(\mathrm{GH})$ levels $>2,5 \mathrm{ng} / \mathrm{ml}$ and/or $\mathrm{GH}$ value $>1 \mathrm{ng} / \mathrm{ml}$ after oral glucose tolerance test (OGTT), and magnetic resonance imaging (MRI) scan of the pituitary gland. Tumors measuring $10 \mathrm{~mm}$ or less in diameter were considered to be microadenomas, and those which exceeded $10 \mathrm{~mm}$, macroadenomas. Most frequent postoperative complications were recorded. Structural complications included cranial nerve impairment, cerebrospinal fluid (CSF) fistula, sinonasal complications (epistaxis, sinusitis) and surgical wound infection. Criteria for diagnosis were clinical: divergent squint for sixth cranial nerve palsy, rhinorrhea for CSF fistula and drainage of purulent nasal secretion.

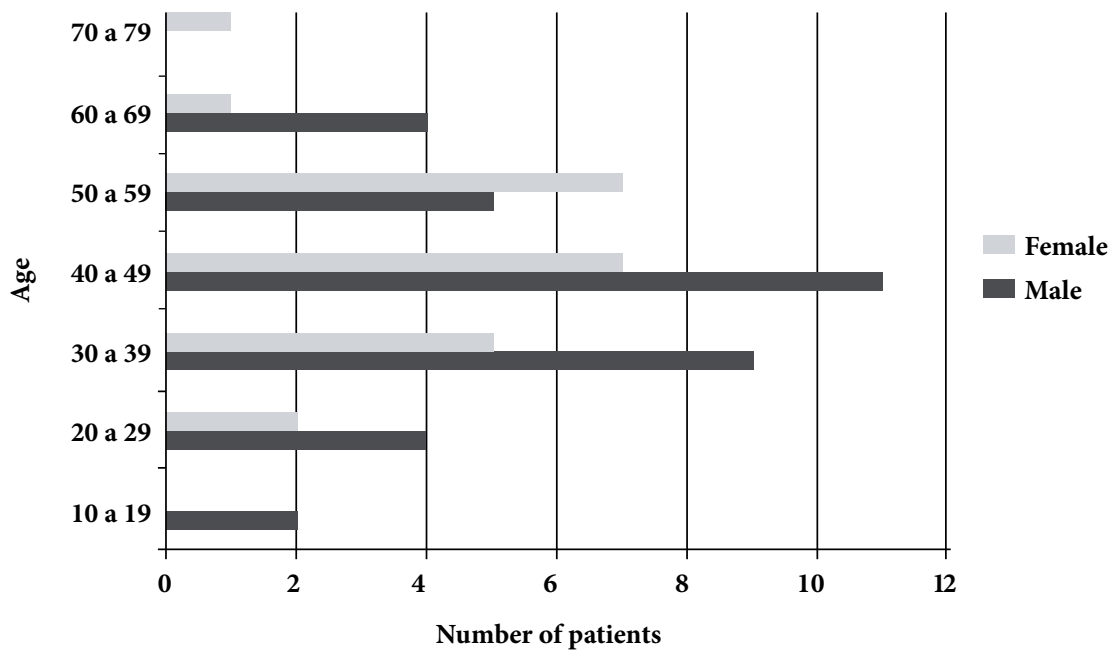

Figure 1 - Age of 58 patients diagnosed with GH secreting pituitary adenomas. 


\section{Results}

Among the 58 patients with $\mathrm{GH}$ secreting adenomas (23 female and 35 male), a lower rate of microadenoma was recorded $(4 / 58,6,9 \%)$. No complications were observed in this group. Fifty-four $(93,1 \%)$ patients were diagnosed with macroadenoma, of which $5(8,6 \%)$ presented postoperative complications. We registered a $29,3 \%(17 / 58)$ rate of invasion of the cavernous sinus. Ten patients $(17,2 \%)$ presented bone invasion at MRI examination and four patients $(4 / 58 ; 6,89 \%)$ presented with both invasion (cavernous sinus and bone invasion).

The incidence of GH secreting adenoma was 1,5 times greater in male patients in our series. Age of patients diagnosed with pituitary adenomas ranged from 10 to 70 years, with a mean age of $43 \pm 12$ years: $44 \pm 19$ years for microadenomas, and $42 \pm 12$ years for macroadenomas (Figure 1). The age of patients who presented complications ranged from 18 to 62 years, with a mean age of $41 \pm 14$ years. The 17 patients with macroadenomas which caused cavernous sinus invasion had a mean age of $45 \pm 11$ years; the 10 cases that macroadenoma caused bone invasion, obtained a mean age of $43 \pm 10$ years. The four cases which had both bone and cavernous sinus invasion, reached a mean age of $36 \pm 12$ years.

Unilateral transient sixth cranial nerve paresis occurred in two $(3,4 \%)$ macroadenoma patients with cavernous sinus invasion. One (1,7\%) patient developed surgical wound infection: drainage of purulent nasal secretion, which was treated with antibiotics and left no sequel. Two cases $(3,4 \%)$ of cerebrospinal fluid fistula were observed in the studied group. In our study, meningitis, carotid artery lesion, epistaxis and death were not reported.

Of five patients who had postoperative complications, four $(80 \%)$ were recorded in the first five years of this series, when approximately one third of the neurosurgeries were performed. In the next eight years, only one case of temporary paresis of the left sixth nerve in 2010 was recorded.

\section{Discussion}

Transsphenoidal surgery usually is the first choice for treatment of pituitary adenomas. According to Marquez et al., ${ }^{6}$ it provides long-term remission in 70$80 \%$ of patients with microadenomas and $50-61 \%$ of patients with macroadenomas, and overall morbidity rates remain extremely low in general. Mortality has been reported in less than $0,5 \%$ of patients treated in high-volume centers. ${ }^{6}$
Even though transsphenoidal surgery is considered a safe treatment, complications may occur. It is well established that the more experienced the surgeon is, lower the rates of complications are. In our series, all procedures were performed by the same neurosurgeon, Luis Alencar Biurrum Borba. Out of the 58 patients treated with GH secreting pituitary adenoma, 5 (8,6\%) presented postoperative complications. In the first five years, 20 transsphenoidal microsurgeries were performed, and $80 \%$ of the structural complications registered in this study happened during this period (4/5). In the next eight years of our study, 38 surgeries were performed, and one case of structural complication was found. This fact corroborates that, in experienced hands, complication rates are low.

Four studies concerning pituitary adenomas in general - not only related to $\mathrm{GH}$ - were reviewed: Marić et al. ${ }^{7}$, Armengot et al. ${ }^{3}$, Santos et al. ${ }^{2}$ and Tamasauskas et al. ${ }^{8}$ Except for the last one, in which patients underwent microsurgery, all studies present results from endoscopic surgery. Macroadenomas were found in 54\% of patients in Marić et al..$^{7}$ series, $97 \%$ in Armengot et al. ${ }^{3}$ and $77 \%$ in both Santos et al. ${ }^{2}$ and Tamasauskas et $a l .{ }^{8}$ The rates of CSF fistula reported were the following: $0,8 \%$ in Marić et al. $; 2,7 \%$ in Armengot et al. ${ }^{3} ; 16,7 \%$ in Santos et al. ${ }^{2}$; and 1,1\% in Tamasauskas et al. ${ }^{8}$ and Marić et al. ${ }^{7}$ also recorded $0,8 \%$ of sixth cranial nerve palsy.

The present study concerns GH secreting pituitary adenomas only, as does Yamada et al. ${ }^{9}$, Minniti et al. ${ }^{10}$, Abosch et al. ${ }^{11}$ and Gondim et al. ${ }^{12}$ In all of these series, patients underwent microsurgery, except for Gondim et al., ${ }^{12}$ in which endoscopic technique was chosen. In our study, $93 \%$ of patients presented macroadenomas, similar to the results reported by Abosch et al. ${ }^{11}$ Yamada et al. ${ }^{9}$, Minniti et al. ${ }^{10}$ and Gondim et al. ${ }^{12}$ registered lower rates: $80 \%, 83 \%$ and $79 \%$, respectively. Invasion of the cavernous sinus occurred in $29 \%$ of patients in our series, in comparison to $20 \%$ in Yamada et al. ${ }^{9}$, Minniti et al. ${ }^{10}$ and $17 \%$ in Abosch et al. ${ }^{11}$ Even though the majority of our patients presented macroadenomas, with a high rate of invasion of surrounding structures, postoperative complications in our studied group is likely the literature review (Table 1).

\begin{tabular}{lccccc}
\hline \multicolumn{5}{c}{ Table 1 - Comparison among GH secreting } \\
pituitary \\
\multicolumn{5}{c}{ Bodenoma series } \\
\hline No cases & 58 & Yamada & Minniti & Abosch & Gondim \\
Macro & $93 \%$ & $84 \%$ & 92 & 254 & 67 \\
Micro & $7 \%$ & $20 \%$ & $17 \%$ & $7 \%$ & $21 \%$ \\
CS inv. & $29 \%$ & $20 \%$ & $25 \%$ & $17 \%$ & NM \\
\hline
\end{tabular}

Macro: macroadenoma; micro: microadenoma; CS inv: cavernous sinus invasion; NM not mentioned. 
Based on Marquez et al., ${ }^{6}$ CSF leakage is the second most common complication of transsphenoidal procedures, the first one being sinonasal complications, such as sinusitis and epistaxis. According to Romero et al., ${ }^{13}$ postoperative CSF fistula rates after microscopic or endoscopic transsphenoidal methods range between 0,5 to $15 \%$. In accordance, Yamada et al. ${ }^{9}$, Minniti et al. ${ }^{10}$ and $17 \%$ in Abosch et al. ${ }^{11}$, Gondim et al. ${ }^{12}$ and ours registered, respectively, the following CSF fistula rates: $2,3 \%, 4,4 \%, 2 \%, 0 \%$ and 3,4\%. According to Romero et al..$^{13}$, and Tamasauskas et al. ${ }^{8}$, there is an increase of postoperative CSF fistula in $\mathrm{GH}$-secreting adenomas. However, such an increase was not observed in our series nor in any of the reviewed ones. Potential morbidities associated with CSF fistula after transsphenoidal surgery includes prolonged hospitalization, reintervention, bacterial meningitis, abscess, subdural hematoma, and hypertensive pneumoencephalus. ${ }^{13}$

Unilateral transient sixth cranial nerve paresis occurred in $3,4 \%$ of patients in our series, all related to invasion of the cavernous sinus. Similar results were recorded in Yamada et al. ${ }^{9}$ study $(4,5 \%)$, also related to invading tumors compromising the cavernous sinus. Meningitis was reported in two studies: Abosch et al. ${ }^{11}$ $(2,0 \%)$ and Minniti et al. ${ }^{10}(1,1 \%)$. Other complications reported included seizure $\left(1,5 \%\right.$ in Gondim et al. ${ }^{12}$ study) and epistaxis (6\% in Gondim's). No carotid artery lesions or deaths were reported by these studies (Table 2).

\begin{tabular}{|c|c|c|c|c|c|}
\hline & Borba & Yamada & Minniti & Abosch & Gondim \\
\hline $6^{\text {th }} \mathrm{CNP}$ & 3,4 & 4,5 & $\mathrm{NM}$ & NM & NM \\
\hline CSF f & 3,4 & 2,3 & 4,4 & 2 & 0 \\
\hline Epistaxis & 0 & NM & NM & NM & 6 \\
\hline Seizure & 0 & NM & NM & NM & 1,5 \\
\hline Mening & 0 & NM & 1,1 & 2 & 0 \\
\hline Death & 0 & 0 & 0 & 0 & 0 \\
\hline
\end{tabular}

NM: not mentioned; $6^{\text {th }}$ CNP: sixth cranial nerve palsy; CSF f: cerebralspinal fluid fistula: mening: meningitis.

\section{Conclusion}

Transsphenoidal surgery is a safe and effective treatment for acromegaly, although it is not free of complications. Rates of complications are inversely proportional to the experience of the neurosurgeon and directly proportional to the size and invasiveness of tumor. Hence the need for reference centers for the treatment of sellar pathology. The rate of postoperative complications in our series is contained within the literature.

\section{Competing interests}

The authors declare no conflict of interest.

\section{References}

1. Krzentowska-Korek A, Gołkowski F, Bałdys-Waligórska A, Hubalewska-Dydejczyk A. Efficacy and complications of neurosurgical treatment of acromegaly. Pituitary. 2011;14(2):157-62.

2. Santos AR, Fonseca Neto RM, Veiga JC, Viana Jr J, Scaliassi NM, Lancellotti CL, et al. Endoscopic endonasal transsphenoidal approach for pituitary adenomas: technical aspects and report of casuistic. Arq Neuropsiquiatr. 2010;68(4):608-12.

3. Armengot M, Gallego JM, Gómez MJ, Barcia JA, Basterra J, Barcia C. Transphenoidal endoscopic approaches for pituitary adenomas: a critical review of our experience. Acta Otorrinolaringol Esp. 2011;62(1):25-30.

4. Katznelson L, Atkinson JL, Cook DM, Ezzat SZ, Hamrahian AH, Miller KK. American Association of Clinical Endocrinologists Medical Guidelines for Clinical Practice for the Diagnosis and Treatment of Acromegaly--2011 update: executive summary. Endocr Pract. 2011;17(4):636-46.

5. Melmed S, Jackson I, Kleinberg D, Klibanski A. Current treatment guidelines for acromegaly. J Clin Endocrinol Metab. 1998;83(8):2646-52.

6. Marquez Y, Tuchman A, Zada G. Surgery and radiosurgery for acromegaly: a review of indications, operative techniques, outcomes, and complications. Int J Endocrinol. 2012;2012:386401.

7. Marić A, Kruljac I, Čerina V, Pećina HI, Šulentić P, Vrkljan M. Endocrinological outcomes of pure endoscopic transsphenoidal surgery: a Croatian Referral Pituitary Center experience. Croat Med J. 2012;53(3):224-33.

8. Tamasauskas A, Sinkūnas K, Draf W, Deltuva V, Matukevicius A, Rastenyte D, et al. Management of cerebrospinal fluid leak after surgical removal of pituitary adenomas. Medicina (Kaunas). 2008;44(4):302-7.

9. Yamada S, Takada K, Ozawa Y, Shimizu T, Sawano S, Shishiba $Y$, et al. The results of transsphenoidal surgery for 44 consecutive acromegalic patients. Endocr J. 1997;44(3):395-402.

10. Minniti G, Jaffrain-Rea ML, Esposito V, Santoro A, Tamburrano G, Cantore G. Evolving criteria for postoperative biochemical remission of acromegaly: can we achieve a definitive cure? An audit of surgical results on a large series and a review of the literature. Endocr Relat Cancer. 2003;10(4):611-9.

11. Abosch A, Tyrrell JB, Lamborn KR, Hannegan LT, Applebury CB, Wilson CB. Transsphenoidal microsurgery for growth hormone-secreting pituitary adenomas: initial outcome and long-term results. J Clin Endocrinol Metab. 1998;83(10):3411-8.

12. Gondim JA, Almeida JP, de Albuquerque LA, Gomes E, Schops M, Ferraz T. Pure endoscopic transsphenoidal surgery for treatment of acromegaly: results of 67 cases treated in a pituitary center. Neurosurg Focus. 2010;29(4):E7.

13. Romero Adel C, Nora JE, Topczewski TE, Aguiar PH, Alobid I, Rodriguéz EF. Cerebrospinal fluid fistula after endoscopic transsphenoidal surgery: experience in a Spanish center. Arq Neuropsiquiatr. 2010;68(3):414-7.

Correspondence address

Marcelo Lemos Vieira da Cunha

Rua Rui Barbosa, 93 E, ap. 501

89801-040 - Chapecó, SC, Brazil

E-mail: marcelolvc@yahoo.com.br 